\title{
Korelasi antara Motivasi Belajar dengan Perencanaan belajar ( Study kasus pada siswa Madrasah Ibtidaiyah (MI) Miftahul Huda Cipayung Ciputat Tangerang Selatan
}

\author{
Endang Iryani \\ (Pendidikan Bahasa Inggris, Fak. Keguruan dan Ilmu Pendidikan Univ. MH Thamrin)
}

\begin{abstract}
ABSTRAK
Pengajar atau guru dengan perencanaan mengajar merupakan satu kesatuan yang tidak bisa dipisahkan. Kemampuan guru dalam merencanakan belajar mengajar di dalam kelas mampu memberikan penilaian terhadap kemampuan seorang guru. Jika guru tidak bisa membuat perencaan belajar yang sesuai dengan keinginan siswanya dikelas maka guru tersebut dianggap gagal untuk menjadi seorang tenaga pendidik.

Perencanaan belajar yang dibuat guru akan menjadi satu kesatuan dengan harapan siswa dikelas (motivasi). Guru bisa mengetahui harapan dan keinganan siswa dengan menganalisa dari karakter siswa tersebut. Motivasi yang melekat dalam diri siswa juga mempengaruhi gaya, dan tujuan siswa belajar dikelas. Sebab, motivasi secara tidak langsung mampu memberikan dorongan tersendiri terhadap keinginan siswa dalam belajar.

Pada penelitian ini, peneliti mencoba mengadakan analisa terhadap perencanaan guru dan motivasi siswa dalam belajar mengajar. Peneliti mengambil objek pada siswa kelas 5 di Madrasah Ibtidaiyah (MI) Miftahul Huda Cipayung Ciputat Tangerang Selatan. Dengan penelitian kuantitatif dan metode penelitian T-Test, kesimpulan dari penelitian ini adalah: a) Hasil penelitian menunjukkan bahwa terdapat hubungan positif perencanaan belajar siswa dengan motivasi belajar siswa pada Madrasah Ibtidaiyah (MI) Miftahul Huda Cipayung Ciputat Tangerang Selatan. Hal ini ditunjukkan dengan signifikansi koefisien thitung sebesar 10,115 pada taraf signifikansi 0,05.

Dari hasil perhitungan diatas diperoleh nilai thitung (10.115) > tabel (1,684), maka Ho ditolak dan Hi diterima atau dengan kata lain bahwa terdapat hubungan yang signifikan antara perencanaan belajar siswa dengan motivasi belajar siswa pada Madrasah Ibtidaiyah (MI) Miftahul Huda Cipayung Ciputat Tangerang Selatan. Hasil statistik tersebut menunjukkan bahwa perencanaan belajar siswa memberikan kontribusi yang signifikan terhadap motivasi belajar siswa. Artinya makin baik perencanaan belajar siswa, maka akan semakin meningkat pula motivasi belajar siswa pada Madrasah Ibtidaiyah (MI) Miftahul Huda Cipayung Ciputat Tangerang Selatan. Perencanaan belajar siswa ditentukan oleh indikator seperti psikologis, social, fisik, financial, pemenuhan kebutuhan, upah, keamanan kerja, kondisi kerja,status, prosedur, prestasi, pengakuan, pekerjaan, tanggung jawab, kemajuan. b) Dari hasil perhitungan statistik menunjukkan bahwa motivasi belajar siswa Madrasah Ibtidaiyah (MI) Miftahul Huda Cipayung Ciputat Tangerang Selatan dapat dihubungi oleh perencanaan belajar siswa dengan signifikansi thitung 10.539 pada taraf signifikansi 0,05.Temuan tersebut menunjukkan bahwa terdapat hubungan positif dan signifikan perencanaan belajar siswa secara bersama-sama dengan motivasi belajar siswa Madrasah Ibtidaiyah (MI) Miftahul Huda Cipayung Ciputat Tangerang Selatan. Prestasi belajar dipengaruhi oleh indikator seperti ketelitian, fokus, bersikap adil, rasional, gunakan waktu, kecakapan, menyelesaikan tugas, persaingan yang sehat, perilaku, mengarahkan, iklim sekolah, potensi, jenjang pendidikan, melatih siswa, faedah.
\end{abstract}




\section{LATAR BELAKANG MASALAH}

Pendidikan mempunyai peranan dalam penyediaan pengetahuan yang beragam, baik dan bermutu. Selain itu pendidikan sangat berperan dalam pembangunan anak nasional. Kekurangan pendidikan atau peningkatan pendidikan dapat menimbulkan gejolak yang dapat berpengaruh terhadap pembangunan anak nasional. Oleh karena itu kualitas pendidikan ini perlu dikembangkan keberadaannya. Dalam pengembangan tersebut tentunya mebutuhkan faktor pendukung seperti sumber daya manusia yang berkualitas.

Pada era transisi dewasa ini, motivasi mempunyai peranan sentral dalam dinamika kehidupan sekolah. Motivasi adalah serangkaian kegiatan (interrelated activities) dalam merencanakan, mengorganisasikan, dan mengawasi yang berhubungan dengan mutu pembelajaran. Memotivasi siswa merupakan salah satu faktor yang menyebabkan meningkatnya mutu pembelajaran pada suatu sekolah. Motivasi adalah bentuk dari pengembangan sumberdaya manusia yang mengarah pada pencapaian keunggulan sekolah karena motivasi adalah bentuk usaha meningkatkan mutu pembelajaran. Motivasi akan membawa dampak positif karena akan mampu meningkatkan kemampuan keterampilan dan sikap siswa terhadap tugas-tugas yang diberikan oleh guru.

Karena suatu dorongan moril (motivasi) berupa perhatian, penghargaan terhadap jerih payah merupakan nilai plus untuk siswa belajar lebih baik lagi, sehingga siswa merasa diperhatikan, diperlukan dan diperlakukan dalam hal ini siswa adalah mitra belajar bukan sebagai objek pekerjaan saja.

Dalam setiap sekolah sumber daya manusia merupakan aset yang sangat penting, karena peranannya sangat menentukan berhasil tidaknya sekolah dalam mencapai tujuannya. Selain itu, keberhasilan dari suatu sekolah juga sangat dipengaruhi oleh kemampuan dan kemauan dari setiap siswa dalam belajar di sekolah. Namun, masalah yang dihadapi oleh setiap sekolah saat ini adalah masih banyaknya para siswa yang akuntabilitasnya rendah dan budaya untuk belajar yang negatif/kurang baik.

Terdapat dua sumber daya yang sangat penting di dalam suatu sekolah baik itu sekolah negeri ataupun swasta. Sumber daya tersebut salah satunya adalah sumber daya manusia yang merupakan unsur manusia itu sendiri seperti guru dan siswa, sedangkan sumber daya bukan manusia adalah sarana dan prasarana yang menunjang kemajuan negara Indonesia, untuk mencapai suatu tujuan maka kedua sumber daya tersebut perlu ditata dengan baik sehingga dapat belajar saling menunjang sesuai dengan fungsinya, untuk mengkoordinasikan sumber daya yang ada maka diperlukan seorang guru.

Perwujudan suatu perencanaan belajar siswa dari suatu sekolah membentuk suatu Rencana Induk (Master Plan) yang komprehensif, yang menyatakan bagaimana sekolah akan mencapai misinya. Perencanaan tersebut memaksimalkan keunggulan kompetitif (competitive advantages) dan meminimalkan kelemahan kompetitif (competitive disadvantages).

Fungsi perencanaan dalam manajemen sumberdaya manusia (MSDM) merupakan kebutuhan nyata untuk mengatasi persoalan yang dihadapi. Proses perencanaan merupakan serangkaian tindakan dan kegiatan mendasar yang dibuat oleh Kepala Sekolah puncak untuk diimplementasikan oleh seluruh jajaran suatu sekolah dalam rangka pencapaian tujuan sekolah.

Pengembangan perencanaan belajar siswa dan implementasinya yang efektif adalah penting untuk kelangsungan hidup sekolah. Kepala Sekolah harus memastikan bahwa perencanaan yang dilakukannya sesuai dengan sekolahnya dan waktunya. Banyak terdapat sekolah yang semula besar dan kuat, tetapi kemudian tidak mampu menjawab tantangan jaman. Sekolah demikian tidak mampu mengembangkan perencanaan belajar siswa pada saat yang tepat atau tidak mampu menjalankan perencanaan secara efektif.

Apa yang ingin dicapai oleh sekolah untuk keberhasilan tidak akan berubah selama bertahun-tahun. Tetapi sebagaimana sekolah tersebut mencapai apa yang diinginkan dapat berubah setiap saat. Perencanaan belajar siswa bisa berubah sebagai hasil usaha para guru yang terus menerus mencoba memperbaiki proses dan hasil. Sekolah harus mengenali dan menghadapi secara efektif perubahan lingkungan belajar yang terjadi terus menerus.

Dengan demikian, perlu adanya kesadaran dari Kepala Sekolah dengan memperhatikan kebutuhan guru akan suasana atau tempat kerja yang memuaskan. Sebab perencanaan belajar siswa yang baik akan mendorong efisiensi dan efektivitas pencapaian tujuan sekolah serta penggunaan tenaga manusia (guru) 
secara efisien tetap merupakan kunci pencapaian motivasi belajar siswa. Perencanaan belajar siswa yang baik, nyaman dan aman merupakan salah satu faktor yang penting bagi terciptanya motivasi belajar siswa. Oleh karena itu, manajemen sekolah perlu memikirkan iklim sekolah atas kualitas guru apabila menginginkan gurunya mempunyai produktivitas kerja yang tinggi.

Untuk menciptakan dan mempertahankan motivasi belajar siswa yang memuaskan, perlu diusahakan adanya perencanaan belajar siswa yang adil dan wajar dimana guru merasa diperlakukan layak sebagai manusia dalam menjalankan tugasnya. Pemberian prasarana guru dapat dilakukan secara jelas.

Dengan demikian, perlu adanya kesadaran dari Kepala Sekolah untuk menciptakan gairah dan peningkatan moral kerja para guru dengan memperhatikan kebutuhan guru tersebut akan suasana dan perencanaan belajar siswa yang memuaskan. Sebab seperti yang penulis kemukakan di atas bahwa kemampuan dan perencanaan belajar siswa yang baik akan mendorong efisien dan efektivitas pencapaian tujuan organisasi serta penggunaan tenaga guru secara efisien tetap merupakan kunci ke arah yang lebih baik.

Jadi usaha Madrasah Ibtidaiyah (MI) Miftahul Huda Cipayung Ciputat Tangerang Selatan untuk meningkatkan motivasi belajar siswa adalah melalui usaha adanya kemampuan dan perencanaan belajar siswa yang baik. Karena program ini merupakan hal yang dapat menyebabkan, menyalurkan, mendukung perilaku manusia supaya mau bekerja giat dan antusias mencapai hasil yang maksimal. Pemenuhan kebutuhan akan kemampuan dan perencanaan belajar siswa merupakan suatu pemeliharaan guru yang sangat penting untuk mempertahankan para guru yang berkualitas dan memiliki kinerja yang bagus.

\section{LINGKUP DAN PERUMUSAN MASALAH PENELITIAN}

Penelitian ini mengambil sample siswa kelas V Madrasah Ibtida eeiyah (MI) Miftahul Huda Cipayung Ciputat Tangerang Selatan yang berjumlah 49 orang. Alasan mengambil kelas 5, sebab siswa kelas 5 sudah mengerti akan emosi, harapan dan keinginan dia. Dan siswa kelas 5 adalah siswa yang menuju tingkat dewasa namun masih bisa dibentuk karakternya oleh guru dan orang tua. Berdasarkan pembatasan masalah diatas, perumusan masalah dalam penelitian ini adalah:

Apakah terdapat hubungan perencanaan belajar siswa dengan motivasi belajar siswa pada Madrasah Ibtidaiyah (MI) Miftahul Huda Cipayung Ciputat Tangerang Selatan?

\section{KERANGKA PEMIKIRAN}

Menurut Stoner (2002:57), perencanaan sekolah berfungsi untuk menentukan jumlah dan jenis siswa yang dibutuhkan untuk mencapai tujuan yang telah ditetapkan. Dalam perencanaan sekolah dibutuhkan pengumpulan dan analisis informasi menurut pendugaan penawaran siswa yang telah tersedia dan prediksi kebutuhan siswa yang akan datang.

Motivasi berasal dari kata "motive" menurut Stoner (2000:215) motive adalah keadaan dalam diri seseorang yang memberi kekuatan menggerakkan atau mendorong dan mengarahkan atau menyalurkan perilaku kearah tercapainya tujuan.

Oleh sebab itu setiap guru akan selalu mengusahakan agar kegiatan yang dilakukan untuk mencapai tujuan yang telah ditetapkan dapat dilakukan dengan cara yang efektif dan efisien. Untuk itu perlu diadakan perencanaan, pengorganisasian, koordinasi kerja dan pengawasan secara baik. Dengan kata lain hal-hal itu semua dilaksanakan agar tujuan yang telah ditetapkan dapat dicapai secara efisien dan efektif. Sehingga dapat disimpulkan dalam diagram bahwa perencanaan belajar adalah X dan Motivasi adalah Y. Dalam tabel bisa digambarkan:

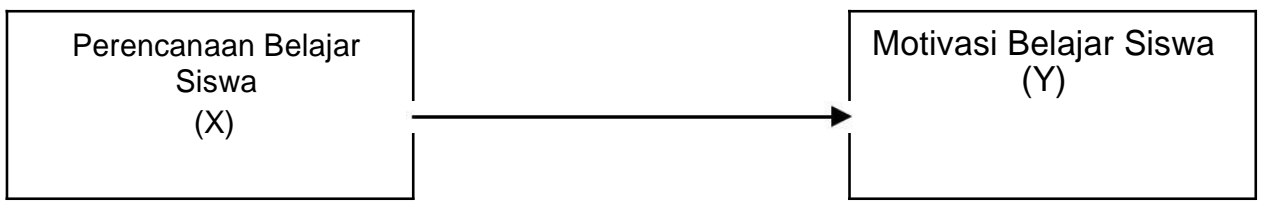




\section{METODE PENELITIAN}

Penelitan ini menggunakan kuantitatif dengan metode T-test. Peneliti melakukan observasi untuk mendapatkan primer dan wawancara pada objek penelitian. Sebagai pendukung data, peneliti juga melakukan study analisis dokumen yang terdapat disekoleh MI Miftahul Huda sebagai data sekunder dalam mendukung data primer.

\section{HASIL PENELITIAN}

Dalam penelitian ini, variabel yang digunakan adalah dua variabel bebas dan satu variabel terikat. Variabel bebas tersebut perencanaan belajar siswa $(\mathrm{X})$ variabel terikatnya adalah motivasi belajar siswa (Y). Data hasil penelitian yang disajikan mulai variabel terikat, kemudian dilanjutkan dengan variabelvariabel bebas lainnya.

Jumlah sumber penelitian yang dianalisis berdasarkan kuesioner yang dinyatakan valid dan reliabel sebanyak 30 butir pernyataan. Proses perhitungan skor yang telah divalidasi dilakukan dengan menggunakan alat bantu komputer. Hal ini dimaksudkan untuk menghindari kesalahan dalam menghitung skor sehingga penelitian dapat dipertanggungjawabkan secara ilmiah.

\section{Pengujian Validitas Data Penelitian}

Setelah dilakukan perhitungan dengan teknik korelasi "product moment" diperoleh koefisien korelasi butir (r-hitung) untuk 15 butir instrumen (kuesioner) dengan sampel sebanyak 49 orang ( $\mathrm{n}=49$ orang), dengan $\alpha=0.05$ didapat $r$ tabel 0.281 , artinya bila $r$ hitung $<\mathrm{r}$ tabel, maka butir instrumen tersebut tidak valid dan apabila $\mathrm{r}$ hitung $>\mathrm{r}$ tabel, maka butir instrumen tersebut dapat digunakan (valid). Dari perhitungan statistik untuk masing-masing variabel, ternyata bahwa $\mathrm{r}$ hitung yang diperoleh lebih besar dari $\mathrm{r}$ tabel, sehingga dikatakan bahwa semua butir kuesioner berpredikat valid. Nilai-nilai koefisien korelasi untuk uji validitas instrumen setiap variabel, disajikan sebagai berikut :

a. Variabel Perencanaan belajar siswa (X)

Nilai koefisien korelasi dari hasil uji validitas untuk variabel perencanaan belajar siswa dapat dilihat pada tabel dibawah ini.

Tabel

Rekapitulasi Nilai r Untuk Uji Validitas Instrumen

Penelitian Variabel Perencanaan belajar siswa (X)

\begin{tabular}{|c|c|c|c|}
\hline $\begin{array}{c}\text { Nomor } \\
\text { Kuesioner }\end{array}$ & r-butir & r-tabel & Keterangan \\
\hline 1 & 0.611 & 0.281 & Valid \\
\hline 2 & 0.373 & 0.281 & Valid \\
\hline 3 & 0.310 & 0.281 & Valid \\
\hline 4 & 0.765 & 0.281 & Valid \\
\hline 5 & 0.546 & 0.281 & Valid \\
\hline 6 & 0.723 & 0.281 & Valid \\
\hline 7 & 0.710 & 0.281 & Valid \\
\hline 8 & 0.796 & 0.281 & Valid \\
\hline 9 & 0.645 & 0.281 & Valid \\
\hline 10 & 0.634 & 0.281 & Valid \\
\hline 11 & 0.284 & 0.281 & Valid \\
\hline 12 & 0.310 & 0.281 & Valid \\
\hline 13 & 0.298 & 0.281 & Valid \\
\hline 14 & 0.374 & 0.281 & Valid \\
\hline 15 & 0.408 & 0.281 & Valid \\
\hline
\end{tabular}


Berdasarkan data yang tertera pada tabel dapat diketahui bahwa nilai koefisien korelasi untuk uji validitas instrumen variabel perencanaan belajar siswa $(\mathrm{X})$ yang diperoleh rata-rata lebih besar dari r-tabel dan seluruh instrumen sebanyak 15 butir dikatakan valid.

b. Variabel Motivasi belajar siswa (Y)

Nilai koefisien korelasi dari hasil uji validitas untuk variabel motivasi belajar siswa dapat dilihat pada tabel.

Tabel

Rekapitulasi Nilai r Untuk Uji Validitas Instrumen

Penelitian Variabel Motivasi belajar siswa (Y)

\begin{tabular}{|c|c|c|c|}
\hline $\begin{array}{c}\text { Nomor } \\
\text { Kuesioner }\end{array}$ & r-butir & r-tabel & Keterangan \\
\hline 1 & 0.618 & 0.281 & Valid \\
\hline 2 & 0.703 & 0.281 & Valid \\
\hline 3 & 0.561 & 0.281 & Valid \\
\hline 4 & 0.651 & 0.281 & Valid \\
\hline 5 & 0.548 & 0.281 & Valid \\
\hline 6 & 0.533 & 0.281 & Valid \\
\hline 7 & 0.650 & 0.281 & Valid \\
\hline 8 & 0.595 & 0.281 & Valid \\
\hline 9 & 0.800 & 0.281 & Valid \\
\hline 10 & 0.463 & 0.281 & Valid \\
\hline 11 & 0.382 & 0.281 & Valid \\
\hline 12 & 0.299 & 0.281 & Valid \\
\hline 13 & 0.284 & 0.281 & Valid \\
\hline 14 & 0.285 & 0.281 & Valid \\
\hline 15 & 0.393 & 0.281 & Valid \\
\hline
\end{tabular}

Berdasarkan data yang tertera pada tabel dapat diketahui bahwa nilai koefisien korelasi untuk uji validitas instrumen variabel motivasi belajar siswa (Y) yang diperoleh rata-rata lebih besar dari $\mathrm{r}$ tabel dan seluruh instrumen sebanyak 15 butir dikatakan valid.

\section{Pengujian Reliabilitas Data Penelitian}

Melalui penghitungan dengan bantuan komputer diperoleh nilai Koefisien Reliabilitas Alpha Cronbach, sebagai berikut:

Tabel

Koefisien Reliabilitas

\begin{tabular}{|c|l|c|}
\hline No. & \multicolumn{1}{|c|}{ VARIABEL } & $\begin{array}{c}\text { Koefisien } \\
\text { Reliabilitas } \\
\text { (Alpha) }\end{array}$ \\
\hline 1. & Perencanaan belajar siswa (X) & 0.794 \\
\hline 2. & Motivasi belajar siswa (Y) & 0.822 \\
\hline
\end{tabular}

Hasil Koefisien Reliabilitas (Alpha) yang tertera pada tabel dapat dikatakan bahwa instrumen yang digunakan andal, artinya suatu instrumen yang dapat dipercaya untuk digunakan sebagai alat 
pengumpul data atau mengukur obyek yang telah ditetapkan karena instrumen tersebut sudah tergolong baik dimana koefisien reliabilitas alpha > dari alpha correctit alpha item correlation.

\section{Analisis Hubungan Perencanaan belajar siswa Dengan Motivasi belajar siswa Pada MI Miftahul Huda Cipayung Ciputat}

Penulis akan melakukan analisis terhadap variabel yang berhubungan dengan motivasi belajar siswa yaitu pengawasan. Variabel bebas tersebut adalah variabel perencanaan belajar siswa $(\mathrm{X})$ serta variabel terikat motivasi belajar siswa (Y). Dari hasil perhitungan diperoleh hasil persamaan sebagai berikut:

Tabel

Koefisien Korelasi Sederhana

Correlations

\begin{tabular}{|ll|r|r|}
\hline & & \multicolumn{1}{|c|}{$\mathrm{y}$} & \multicolumn{1}{c|}{$\mathrm{x}$} \\
\hline Pearson Correlation & $\mathrm{y}$ & 1.000 & .828 \\
& $\mathrm{x}$ & .828 & 1.000 \\
\hline Sig. (1-tailed) & $\mathrm{y}$ &. & .000 \\
& $\mathrm{x}$ & .000 &. \\
\hline $\mathrm{N}$ & $\mathrm{y}$ & 49 & 49 \\
& $\mathrm{x}$ & 49 & 49 \\
\hline
\end{tabular}

Berdasarkan tabel di atas dapat disimpulkan bahwa:

1. Hubungan antara $X$ (perencanaan belajar siswa) dengan $Y$ (motivasi belajar siswa)

Hubungan antara $X$ (perencanaan belajar siswa) dengan $Y$ (motivasi belajar siswa) adalah sebesar 0,828 menunjukkan hubungannya positif yang berarti bahwa apabila perencanaan belajar siswa meningkat, maka motivasi belajar siswa juga meningkat atau sebaliknya. Selain itu hubungannya juga kuat karena lebih besar dari 0,5 artinya apabila terjadi perubahan pada $X$ (perencanaan belajar siswa) maka akan segera merubah Y (motivasi belajar siswa).

Untuk mengetahui hubungan variabel X1 terhadap variabel $\mathrm{Y}$, dapat digunakan analisis

Koefisien Determinasi (Kd) yaitu sebagai berikut:

$$
\begin{aligned}
\mathrm{Kd} & =\mathrm{r}^{2} \times 100 \% \\
& =(0,828)^{2} \times 100 \% \\
& =0,685 \times 100 \% \\
& =68,5 \%
\end{aligned}
$$

Sedangkan koefisien determinasinya $\left(\mathrm{r}^{2}\right)$ adalah 0,685 yang berarti motivasi belajar siswa 68,5 $\%$ ditentukan oleh perencanaan belajar siswa dan sisanya ditentukan oleh faktor lain sebesar $31,5 \%$.

2.Hubungan antara perencanaan belajar siswa $(X)$ secara bersama-sama dengan motivasi belajar

\begin{tabular}{|c|c|c|c|c|}
\hline Model & $\mathrm{R}$ & R Square & $\begin{array}{l}\text { Adjusted } \\
\text { R Square }\end{array}$ & $\begin{array}{l}\text { Std. Error of } \\
\text { the Estimate }\end{array}$ \\
\hline 1 & $.838^{a}$ & .702 & .679 & 3.93910 \\
\hline
\end{tabular}
siswa (Y).

Tabel b

Model Summary 
Berdasarkan tabel diketahui bahwa nilai koefisien korelasi berganda $(\mathrm{R})=0.838$ yang berarti hubungan variabel perencanaan belajar siswa $(\mathrm{X})$ dengan variabel terikat motivasi belajar siswa (Y) menunjukkan hubungan yang positif.

Untuk mengetahui hubungan variabel $\mathrm{X}$ terhadap variabel $\mathrm{Y}$, dapat digunakan analisis Koefisien Determinasi (Kd) yaitu sebagai berikut :

$$
\begin{aligned}
\mathrm{Kd} & =\mathrm{r}^{2} \times 100 \% \\
& =(0,838)^{2} \times 100 \% \\
& =0,702 \times 100 \% \\
& =70,2 \%
\end{aligned}
$$

Sedangkan besarnya koefisien determinasi atau $\mathrm{R}$ Square sebesar 0.702 yang merupakan pengkuadratan dari koefisien korelasi. Hal ini menunjukkan 70,2\% variabel motivasi belajar siswa (Y) ditentukan oleh faktor variabel perencanaan belajar siswa (X) sedangkan sisanya 29,8\% ditentukan faktor-faktor lain dalam penelitian ini.

Dalam pembahasan hasil penelitian ini dilakukan dari tiga segi, yaitu hasil analisis pengaruh antar variabel. Hasil analisis tiap variabel menunjukkan bahwa:

a. Hubungan Perencanaan belajar siswa dengan Motivasi belajar siswa

Hasil penelitian menunjukkan bahwa terdapat hubungan positif perencanaan belajar siswa dengan motivasi belajar siswa pada MI Miftahul Huda. Hal ini ditunjukkan dengan signifikansi koefisien thitung sebesar 10,115 pada taraf signifikansi 0,05.

Dari hasil perhitungan diatas diperoleh nilai thitung $(10.115)>$ tabel $(1,684)$, maka Ho ditolak dan Hi diterima atau dengan kata lain bahwa terdapat hubungan yang signifikan antara perencanaan belajar siswa dengan motivasi belajar siswa pada MI Miftahul Huda. Hasil statistik tersebut menunjukkan bahwa perencanaan belajar siswa memberikan kontribusi yang signifikan terhadap motivasi belajar siswa. Artinya makin baik perencanaan belajar siswa, maka akan semakin meningkat pula motivasi belajar siswa pada MI Miftahul Huda. Perencanaan belajar siswa ditentukan oleh indikator seperti psikologis, social, fisik, financial, pemenuhan kebutuhan, upah, keamanan kerja, kondisi kerja,status, prosedur, prestasi, pengakuan, pekerjaan, tanggung jawab, kemajuan.

b. Hubungan Perencanaan belajar siswa secara bersama-sama dengan Motivasi belajar siswa

Dari hasil perhitungan statistik menunjukkan bahwa motivasi belajar siswa MI Miftahul

Huda dapat dihubungi oleh perencanaan belajar siswa dengan signifikansi thitung 10.539 pada taraf signifikansi 0,05 .

Temuan tersebut menunjukkan bahwa terdapat hubungan positif dan signifikan perencanaan belajar siswa secara bersama-sama dengan motivasi belajar siswa MI Miftahul Huda. Prestasi belajar dipengaruhi oleh indikator seperti ketelitian, fokus, bersikap adil, rasional, gunakan waktu, kecakapan, menyelesaikan tugas, persaingan yang sehat, perilaku, mengarahkan, iklim sekolah, potensi, jenjang pendidikan, melatih siswa, faedah.

\section{KESIMPULAN}

Dari hasil penelitian diperoleh kesimpulan sebagai berikut:

1. Hasil penelitian menunjukkan bahwa terdapat hubungan positif perencanaan belajar siswa dengan motivasi belajar siswa pada MI Miftahul Huda. Hal ini ditunjukkan dengan signifikansi koefisien thitung sebesar 10,115 pada taraf signifikansi 0,05. Dari hasil perhitungan diatas diperoleh nilai thitung $(10.115)>t_{\text {tabel }}$ $(1,684)$, maka Ho ditolak dan Hi diterima atau dengan kata lain bahwa terdapat hubungan yang signifikan antara perencanaan belajar siswa dengan motivasi belajar siswa pada MI Miftahul Huda. Hasil statistik tersebut menunjukkan bahwa perencanaan belajar siswa memberikan kontribusi yang signifikan terhadap motivasi belajar siswa. Artinya makin baik perencanaan belajar siswa, maka akan semakin meningkat pula motivasi belajar siswa pada MI Miftahul Huda. Perencanaan belajar siswa ditentukan oleh indikator seperti psikologis, social, fisik, financial, pemenuhan kebutuhan, upah, 
keamanan kerja, kondisi kerja,status, prosedur, prestasi, pengakuan, pekerjaan, tanggung jawab, kemajuan.

2. Dari hasil perhitungan statistik menunjukkan bahwa motivasi belajar siswa MI Miftahul Huda dapat dihubungi oleh perencanaan belajar siswa dengan signifikansi thitung 10.539 pada taraf signifikansi 0,05.Temuan tersebut menunjukkan bahwa terdapat hubungan positif dan signifikan perencanaan belajar siswa secara bersama-sama dengan motivasi belajar siswa MI Miftahul Huda. Prestasi belajar dipengaruhi oleh indikator seperti ketelitian, fokus, bersikap adil, rasional, gunakan waktu, kecakapan, menyelesaikan tugas, persaingan yang sehat, perilaku, mengarahkan, iklim sekolah, potensi, jenjang pendidikan, melatih siswa, faedah.

\section{Daftar Pustaka}

Adelfer, 2000, Organizational Behavior, New Jersey : Prentice Hall Englewood Cliffs. Agus Sunyoto, 2000, Manajemen Sumber Daya Manusia, Penerbit IPWI, Jakarta.

Bambang Wahyudi, 2003, Manajemen Personalia dan Sumber Daya Manusia, Universitas Gajah Mada, Yogyakarta.

B. Flippo, Edwin, 1996, Principle Of Manajemen, PT. Liberty, Yogyakarta.

David Mc Clelland, 2001, Memacu Masyarakat Berprestasi, (terj. Siswo Suyanti dan Wilhelmus W. Bakowatun), Intermedia, Jakarta.

Hadari Nawawi, 1992, Pengawasan Melekat, Erlangga, Jakarta.

Handoko T. Hani, 2001, Manajemen Personalia dan Sumber Daya Manusia, BPFE, Yogyakarta.

Handoko T. Hani, 1999, Manajemen, BPFE, Yagyakarta.

Handayaningrat Suwarno, 1998, Manajemen Sumber Daya Manusia, Jakarta : Ghalia.

Herzberg, Frederick, 2001, Organizational Behavior, The Management of Individual and Organizational Performance, Massachuseet-USA: Allyn-Bacon.

Jucius, Michael J, 2000, Personal Management, Charles E, Tuttle Company, Tokyo.

Krisna, Eri, 2003, Definisi Kualitas, PT. Rosda Karya, Jakarta.

Maslow Abraham, H., 2000, Motivasi dan Kepribadian, Jilid I dan II, Terjemahan Nurul Imam, Pustaka Binaan Pressindo, Jakarta.

Moh. Agus, Tulus, 2001, Manajemen Sumber Daya Manusia, Penerbit Rineka Cipta.

Moh. As sead, 2001, Manajemen Motivasi, PT. Galaxy Karya Abadi, Jakarta.

Ndraha, Talizidhu ,2002, Manajemen Sumber Daya Manusia, PT. Anugrah Ilmu, Jakarta.

Nitisemito, 2002, Manajemen Personalia, PT. Wahana Aksara. Jakarta.

Prayudi Atmosudirjo, 2002, Administrasi dan Manajemen Umum, Edisi I, Universitas Krisnadwipayana, Jakarta.

Robbins, 2000, Proses Pelayanan, PT. Indah Nusa Cipta, Jakarta.

Silalahi, Bennet, 2000, Manajemen Sumber Daya Manusia, Sekolah Tinggi Ilmu Manajemen LPMI.

Siagian, Sondang, 2003, Manajemen SDM, Bumi Aksara, Jakarta.

Siagian, Sondang, 2003, Manajemen SDM, Bumi Aksara, Jakarta.

Siagian Sondang, 1998, Peranan Staff dalam Manajemen, Gunung Agung Jakarta.

Simamora, Henry, 1999, Manajemen Sumber Daya Manusia, Penerbit Bagian Penerbitan STIE YKPN, Yogyakarta.

Soewarno Handayaningrat, 2004, Pengantar Study Ilmu Administrasi dan Manajemen, Gunung Agung, Jakarta.

Stoner, James A.F. dan Freeman, 2000, Manajemen, Erlangga, Jakarta.

Tjiptono, 1999, Pengetian Kualitas, PT. Grafika Intermedia Cipta, Jakarta.

The Liang Gie dan Sutanto, 1997, Pengertian, Kedudukan dan Perincian Ilmu Administrasi, Cetakan Kedua Karya Kencana, Yogyakarta.

Victor Vroom, 2002, The Motivation to Work, New York Wiley.

Viencent, Gosperz, 2001, Personnel Management, $3^{\text {rd }}$ Eition. Restoran Publising Company Inc. 